\section{Planting Depth and Seed Size Affect Edamame Emergence Individually}

\author{
Laura E. Crawford \\ University of Illinois, Department of Crop Sciences, 1102 South Goodwin \\ Avenue, Urbana, IL 61801
}

Martin M. Williams, $\mathbf{I I}^{\mathbf{1}}$

U.S. Department of Agriculture-Agricultural Research Service, Global Change and Photosynthesis Research, 1102 South Goodwin Avenue, Urbana, IL 61801

Additional index words. Glycine max, planting depth, seed size

\begin{abstract}
Edamame growers currently rely heavily on planting depth recommendations for grain-type soybean, despite stark differences in seed characteristics between the two types of cultivars, most notably seed size. Therefore, the objective of the study was to determine the effects of planting depth and seed size on edamame emergence. A popular edamame cultivar used in commercial production was sorted into "small" $(23.7 \mathrm{~g} / 100$ seed) and "large" (36.8 g/100-seed) seed-size classes, then planted at depths of 1.0, 2.0, 3.0 , and $5.0 \mathrm{~cm}$ in field experiments. Experiments were conducted in four environments as a split-plot experimental design with four replications. Seed size did not influence total emergence; however, small seed emerged $10 \%$ faster than large seed. Although planting depth recommendations for grain-type soybean are 3.2 to $4.5 \mathrm{~cm}$, our results showed edamame emerged more completely and quicker at the shallowest depths examined. The research could be expanded to capture greater diversity in growing environments and crop cultivars; however, the vegetable industry now has research-based information to guide preliminary recommendations regarding appropriate planting depth of edamame.
\end{abstract}

Edamame [Glycine max (L.) Merr.] is an emerging health food in the United States; however, imports from Asia have been commonplace (Dong et al., 2014). Horticultural research to facilitate domestic edamame production on a commercial scale is limited. The vegetable industry currently relies heavily on established grain-type soybean management guidelines, despite stark differences between the two types of cultivars and their end-use products (Williams, 2015; Zhang et al., 2013). Although some management techniques might translate from grain-type soybean to edamame, research to confirm or deny their appropriateness is lacking.

Poor emergence is a common theme in field research on edamame (Duppong and Hatterman-Valenti 2005; Rao et al., 2002; Sanchez et al., 2005; Williams, 2015). Seedling emergence is affected by interactions among biotic, edaphic, and management factors (Arndt, 1965; Hamman et al., 2002). Aspects of crop

Received for publication 10 Oct. 2018. Accepted for publication 31 Oct. 2018.

This research was supported by U.S. Department of Agriculture-Agricultural Research Service research project no. 5012-12220-009-00-D.

We thank Jim Moody, Nick Hausman, and undergraduate students for their help.

Mention of a trademark, proprietary product, or vendor does not constitute a guarantee or warranty of the product by the U.S. Department of Agriculture and does not imply its approval to the exclusion of other products or vendors that also may be suitable.

${ }^{1}$ Corresponding author. E-mail: martin.williams@ ars.usda.gov. management that could be altered to improve edamame emergence are essential for growth in domestic edamame production.

Appropriate planting depth is an essential management decision for all annual crops. Recommended planting depth of grain-type soybean is 3.2 to $4.5 \mathrm{~cm}$ (Hummel et al., 1981; Nafziger, 2009). Study on how planting depth affects edamame emergence is limited. In a growth chamber experiment, Zhang et al. (2013) reported highest emergence of edamame from pots was from a planting depth of $1.0 \mathrm{~cm}$. The extent to which the controlled environment study relates to field production systems is unclear. To the best of our knowledge, research-based information to guide recommendations for planting depth of edamame are nonexistent.

One of the biggest differences between grain-type soybean and edamame that may affect crop emergence is seed size. Edamame seed mass is $\approx 30 \mathrm{~g} / 100$-seed compared with 15 to $20 \mathrm{~g} / 100$-seed for grain-type soybean (Bernard, 2005; Dong et al., 2014; Williams, 2015). The literature is inconclusive on how seed size affects soybean emergence, but most studies find that seed size and emergence are inversely related. Within a cultivar, Adebisi et al. (2013), Burris et al. (1973), Hoy and Gamble (1987), and Kering and Zhang (2015) report that "small" seed have as much as $11 \%$ higher emergence than "large" seed. Are within-cultivar seed-size effects of grain-type soybean emergence also observed in the much larger seeded edamame?

This study aimed to determine the extent to which edamame emergence can be im- proved through planting depth and seed size. Therefore, the objective was to determine the effects of planting depth and seed size on edamame emergence.

\section{Materials and Methods}

Germplasm and seed sizing. A popular cultivar used in commercial production, Midori Giant (Wannamaker Seeds, Inc., Saluda, NC), was used in the experiment. Seed were separated into discrete size classes with a seed cleaner (Clipper Cleaner, A. T. Ferrell Company, Bluffton, IN). The seed cleaner has round holed screens ranging from 0.71 to $1.07 \mathrm{~cm}$ diameters in $0.04-\mathrm{cm}$ increments. Individual seed size classes were then grouped into "small" and "large" aggregate size classes in such a way that size classes had approximately equal quantities of seed. The aggregate small-size class included seed less than $0.79 \mathrm{~cm}$ in diameter with an average seed diameter of $0.77 \mathrm{~cm}$. The aggregate large size class included seed greater than $0.87 \mathrm{~cm}$ in diameter with an average seed diameter of $0.91 \mathrm{~cm}$. Seed with diameter larger than 0.79 but smaller than 0.87 were omitted to make discrete seed size classes. Additional details regarding seed size classes are shown in Table 1. To minimize the effect of soil-borne pathogens on crop emergence, seeds were treated with mefenoxam $(3.37 \mathrm{~g}$ per $100 \mathrm{~kg}$ of seed) and fludioxonil $(2.27 \mathrm{~g}$ per $100 \mathrm{~kg}$ seed; Apron Maxx, Syngenta Crop Protection, Greensboro, NC) before planting.

Site characterization. Experiments were conducted in four adjoining fields in 2016 at the University of Illinois Vegetable Crop Farm in Urbana, IL. The previous crop was grain soybean. The soil was a Flanagan silt loam averaging $3.3 \%$ organic matter and a $\mathrm{pH}$ of 5.8. Before planting each experiment, the seedbed was prepared with a disc harrow and a field cultivator to create a fine seedbed texture and ensure seed-to-soil contact.

Before planting each experiment, the planter was calibrated in the field to determine row unit settings to achieve planting depths. Specifically, a trial-and-error approach was used to manually adjust each row unit to target planting depths. Planting depths were confirmed by uncovering $\approx 12$ seeds of each treatment and measuring from the top of the seed to the soil surface. Planting was done with a four-row cone planter with a 76-cm row spacing (ALMACO, Nevada, IA).

Experimental design. The experimental design was a split-plot randomized complete block with four replications. To capture a range of environmental conditions during emergence, the experiment was conducted four consecutive times in adjoining fields (hereafter called runs A, B, C, and D). Planting dates of runs A, B, C, and D were 25 May, 20 June, 12 July, and 10 Aug. 2016, respectively. The main plot factor was planting depth with four levels based on recommendations for grain-type soybean (Hummel et al., 1981; Nafziger, 2009). Depths ranged from shallower than recommended $(1.0,2.0$, and $3.0 \mathrm{~cm}$ ) and deeper than recommended 
$(5.0 \mathrm{~cm})$. The main plot experimental unit was two rows measuring $2.4 \mathrm{~m}$ in length. The subplot factor was seed size, using the small and large size classes described earlier. The subplot experimental unit was a single row measuring $2.4 \mathrm{~m}$ in length planted with 50 seeds.

Data collection and analysis. Emergence counts were made daily until all plants had at least one fully unfurled trifoliate leaf. Seedlings were considered emerged when hypocotyls were completely free of the soil surface. Cumulative precipitation and average daily soil temperature under bare soil conditions at a $5.0-\mathrm{cm}$ depth were obtained from a weather station less than $1 \mathrm{~km}$ from the experimental site (Illinois State Water Survey, Champaign, IL).

On the basis of residual analysis, emergence data met analysis of variance (ANOVA) assumptions of normality, equality of variances, and independence (Hox, 2002). Total emergence and days to $50 \%$ emergence were analyzed with an ANOVA model using the mixed procedure in SAS (version 9.4, SAS Institute Inc., Cary, NC). Seed size and planting depth were considered fixed effects. Run and rep nested in run were treated as random effects. Values followed by different letters are significantly different at $\alpha=0.05$ based on the Tukey's means separation test.

\section{Results}

Environmental conditions. Soil temperature and moisture conditions during the experiment were favorable for crop emergence. On most days, average daily soil temperature at the $5.0-\mathrm{cm}$ depth ranged from 24 to $32{ }^{\circ} \mathrm{C}$ (Fig. 1). Cumulative precipitation was $7.2 \mathrm{~cm}$ or greater during the period of crop emergence (Fig. 2); however, localized flooding (i.e., standing water) was never observed. No signs of cold, heat, or water stress were observed. Moreover, soil crusting was not evident.

Total emergence. Seed size did not affect total emergence $(P=0.484)$. Average total emergence was $58.6 \%$ (Table 2 ).

Planting depth affected total emergence $(P<0.001)$. The three shallowest depths $(1.0$, 2.0 , and $3.0 \mathrm{~cm}$ ) had higher emergence than the deepest depth $(5.0 \mathrm{~cm})$. The shallow depths had an average emergence of $63.5 \%$, and the deepest depth had $44.1 \%$ emergence (Table 2 ). No interaction was observed between seed size and planting depth $(P=0.825)$.

Emergence Timing. Both seed size and planting depth affected time to $50 \%$ emergence $(P=0.002$ and $P<0.001$, respectively). Large seed took $0.7 \mathrm{~d}$ longer to reach $50 \%$ emergence than small seed (Table 2).

As depth increased, time to $50 \%$ emergence increased (Table 2). The two shallowest depths $(1.0$ and $2.0 \mathrm{~cm})$ had $19 \%$ faster emergence than the deepest depth $(5.0 \mathrm{~cm})(P<0.001)$. There was no interaction between seed size and planting depth on time to $50 \%$ emergence $(P=0.435)$.

\section{Discussion}

Edamame seed size influences the rate of crop emergence, with small seed emerging

Table 1. Edamame seed characteristics of two seed size classes used in planting depth experiments near Urbana, IL.

\begin{tabular}{lcccc}
\hline Seed size & $\begin{array}{c}\text { Seed diameter } \\
\text { threshold }(\mathrm{cm})\end{array}$ & $\begin{array}{c}\text { Average seed } \\
\text { diameter }(\mathrm{cm})\end{array}$ & $\begin{array}{l}100-\text {-seed } \\
\text { mass }(\mathrm{g})\end{array}$ & Germination $(\%)$ \\
\hline Small & $<0.79$ & 0.77 & 23.7 & 93.0 \\
Large & $>0.87$ & 0.91 & 36.8 & 93.5 \\
\hline
\end{tabular}

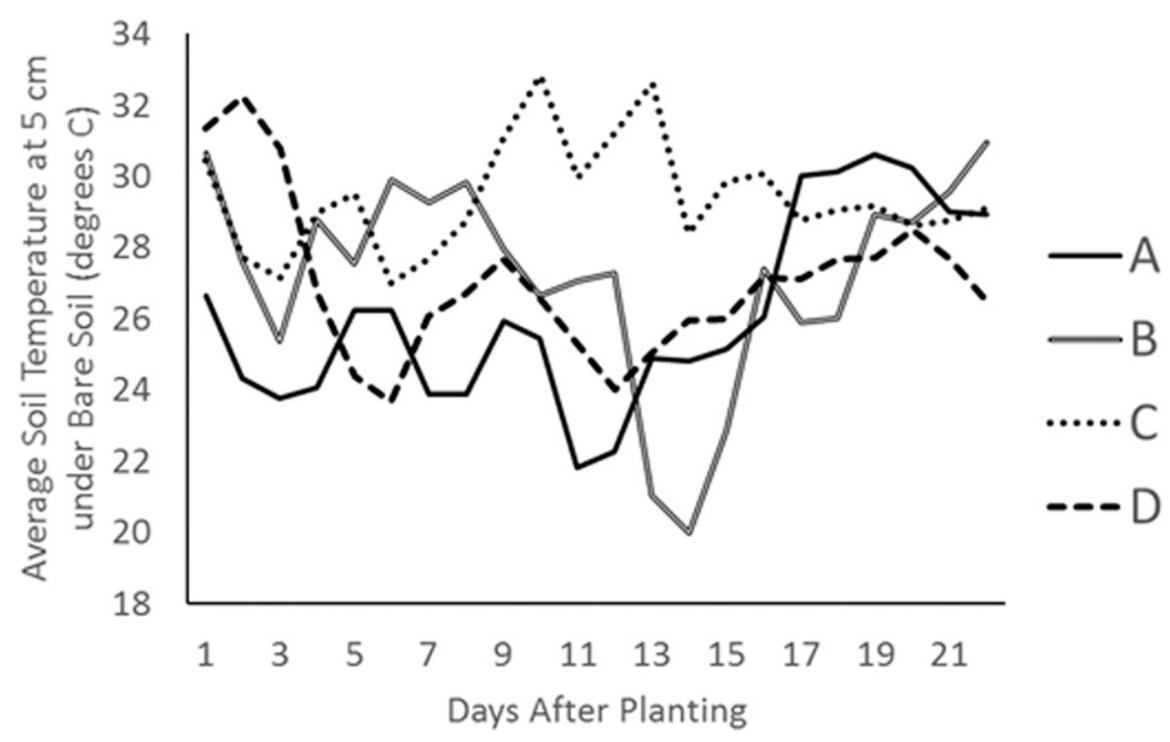

Fig. 1. Average daily soil temperature at a 5-cm depth under bare soil conditions for experimental runs in adjoining fields A, B, C, and D near Urbana, IL. Planting dates of runs A, B, C, and D were 25 May, 20 June, 12 July, and 10 Aug. 2016, respectively.

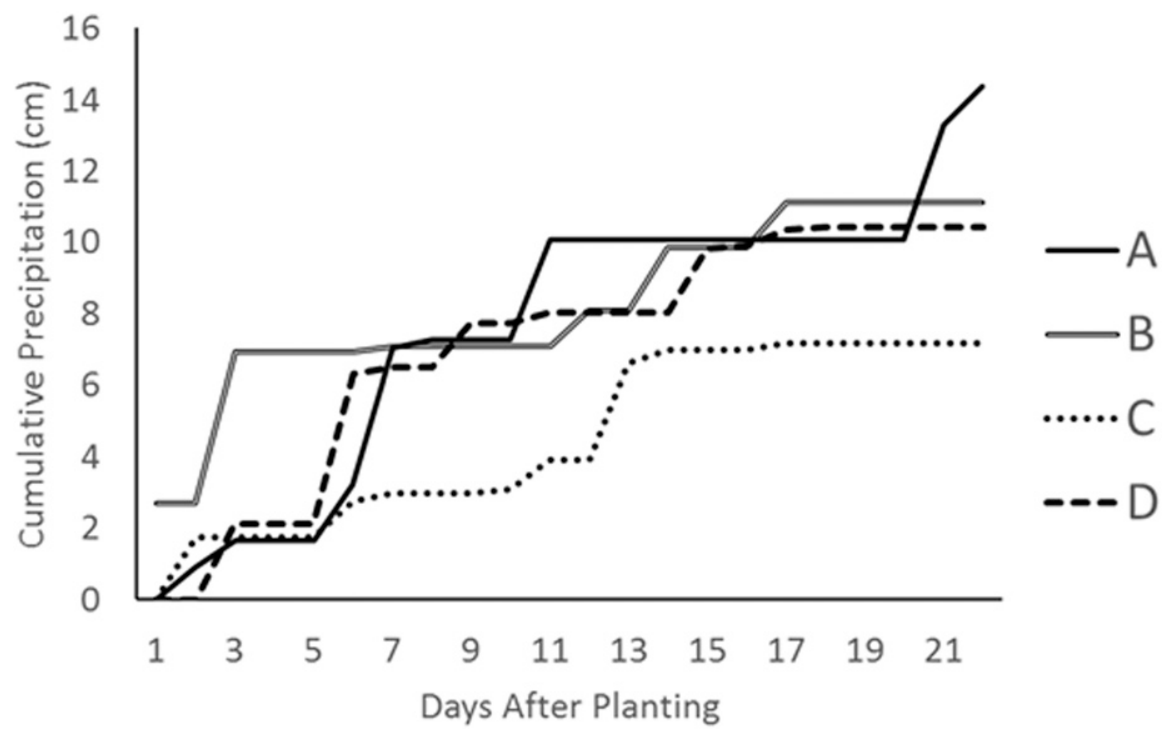

Fig. 2. Cumulative precipitation for experimental runs in adjoining fields $\mathrm{A}, \mathrm{B}, \mathrm{C}$, and $\mathrm{D}$ near Urbana, IL. Planting dates of runs A, B, C, and D were 25 May, 20 June, 12 July, and 10 Aug. 2016, respectively.

$10 \%$ faster than large seed. Others have observed greater germination rates of "small" compared with "large" soybean seed (Abebisi et al., 2013; Edwards and Hartwig 1971). There are several possible explanations for faster emergence of small seed in the present research. One explanation could be the rate at which seed are fully imbibed for germination. A soybean seed must imbibe $\approx 50 \%$ of its mass to initiate germination. As seed size decreases, less water is imbibed to initiate germination, which could result in faster emergence for small seed (Kering and Zhang, 2015). Within cultivar, Adebisi et al. (2013) found that small seed germinated earlier than large seed, an observation that also was attributed to rate of seed imbibition. Alternatively, germinating large seed could be subjected to greater mechanical resistance in the soil that might slow emergence. Burris et al. (1973) concluded that smaller seed within a given cultivar had higher emergence because there was less mechanical resistance on emerging seedlings. 
Table 2. Total edamame emergence and time to $50 \%$ emergence in field experiments near Urbana, IL. Significance $(\mathrm{P})$ of main effects and their interaction are included. ${ }^{\mathrm{z}}$

\begin{tabular}{lccc}
\hline Factor & Level & $\begin{array}{c}\text { Total } \\
\text { emergence }(\%)\end{array}$ & $\begin{array}{c}\text { Time to } 50 \% \\
\text { emergence (d) }\end{array}$ \\
\hline Size & Small & 57.7 & $6.4^{\mathrm{b}}$ \\
& Large & 59.5 & $7.1^{\mathrm{a}}$ \\
Depth $(\mathrm{cm})$ & $P$ value & 0.484 & 0.002 \\
& 1.0 & $62.9^{\mathrm{a}}$ & $5.9^{\mathrm{b}}$ \\
& 2.0 & $67.4^{\mathrm{a}}$ & $6.4^{\mathrm{b}}$ \\
& 3.0 & $60.1^{\mathrm{a}}$ & $7.1^{\mathrm{ab}}$ \\
& 5.0 & $44.1^{\mathrm{b}}$ & $7.6^{\mathrm{a}}$ \\
Size * depth & $P$ value & $<0.001$ & $<0.001$ \\
${ }^{\mathrm{z}}$ Values & $P$ value & 0.825 & 0.435 \\
\hline
\end{tabular}

${ }^{\mathrm{z}}$ Values followed by different letters are significantly different at $\alpha=0.05$ based on Tukey's means separation test.

Seed size did not influence total emergence. Using the same method as used here to create small and large seed size classes, Crawford and Williams (2018) found no difference in emergence of five commercially used edamame cultivars. Germination of most seed lots were nearly identical between small and large seed size classes. These results are contrary to some previous research on grain-type soybean. Several authors have reported seed lots of smaller mass (by 4 to 14 $\mathrm{g} / 100$-seed) having $2 \%$ to $11 \%$ higher germination and emergence than larger seed (Adebisi et al., 2013; Burris et al., 1973; Hoy and Gamble 1987; Kering and Zhang 2015). In contrast, Longer et al. (1986) reported that decreasing seed mass by $1.5 \mathrm{~g} /$ 100 -seed decreased emergence by $13 \%$. However, TeKrony et al. (1987) observed no effect of seed size on soybean emergence under "near ideal" environmental conditions. Despite sampling four environments, weather conditions in the present study were excellent for edamame emergence. Edaphic factors likely play a larger role on edamame emergence than within-cultivar seed mass.

In general, crop emergence and emergence rate declined with planting depth. Several studies report a negative relationship between grain-type soybean emergence and planting depth (Hamman et al., 2002; Hummel et al., 1981). Deeper planting depths reduce emergence because of mortality due to the detrimental effects of delayed emergence. Delayed emergence extends the window of time in which seedlings are vulnerable to soil pathogens (Canakci et al., 2009; Hamman et al., 2002). In addition, anaerobic conditions increase with soil depth, contributing to seedling mortality (Hummel et al., 1981). Finally, a longer time period from planting to emergence subjects the soil surface to variable weather, thereby increasing the risk of seeding mortality from a soil-crusting event (Canakci et al., 2009).

Planting too shallow also can be detrimental to soybean emergence in certain cases. When water is limiting, shallow depths may not have sufficient soil moisture for soybean germination (Hummel et al., 1981). Insufficient soil moisture can also cause mortality in shallowly rooted seedlings. Madanzi et al. (2010) observed exposed roots in shallow plantings, which exacerbated mortality in water-limited environments. In the present study, water was not limiting during the emergence period.

The optimal planting depth of edamame is different from the recommendation for graintype soybean. Total emergence from the 1.0-, $2.0-$, and $3.0-\mathrm{cm}$ planting depths was similar based on Tukey's means separation, although numerically was from the $2.0-\mathrm{cm}$ depth (Table 2). Although growth chamber research showed edamame emergence declined with planting depth greater than $1.0 \mathrm{~cm}$ (Zhang et al., 2013), results from the present field experiments may reflect a greater degree of realism to commercial edamame production. There also was a trend for deeper plantings to have slower emergence rates. In any event, these results show the optimal planting depth of edamame may be shallower than grain-type soybean.

In a soil common to Illinois, our results show edamame emergence was greatest when planted at the shallowest depths. For seed sizes that varied from 23.7 to $36.8 \mathrm{~g} /$ 100 -seed, the small seed size class emerged $10 \%$ faster than the large seed size class. Although this research took an initial step in determining the effects of planting depth and seed size on edamame emergence, the scope of work could be broadened in future research. To capture a wider range of environments in which edamame is grown, a greater sampling of soils and weather in planting depth research would be valuable. Ideally, future research on this issue will include more of the diversity of seed and emergence traits observed across edamame cultivars. In the meantime, the vegetable industry now has research-based information to guide preliminary recommendations regarding appropriate planting depth of edamame.

\section{Literature Cited}

Adebisi, M.A., T.O. Kehinde, A.W. Salau, L.A. Okesola, J.B.O. Porbeni, A.O. Esuruoso, and K.O. Oyekale. 2013. Influence of different seed size fractions on seed germination, seedling emergence, and seed yield characters in tropical soybean (Glycine max L. Merrill). Intl. J. Agr. Res. 8:26-33.

Arndt, W. 1965. The nature of the mechanical impedance to seedlings by soil surface seals. Austral. J. Soil Res. 3:45-54.

Bernard, R. 2005. Garden-type vegetable soybean varieties. Illinois Agricultural Experiment Station, Urbana, IL. it is also worth noting the highest emergence
Burris, J.S., O.T. Edje, and A.H. Wahab. 1973. Effects of seed size on seedling performance in soybeans: II. Seedling growth and photosynthesis and field performance. Crop Sci. 13:207210.

Canakci, M., D. Karayel, M. Topakci, and A. Koc. 2009. Performance of a no-till seeder under dry and wet soil conditions. Appl. Eng. Agr. 25:459-465.

Crawford, L.E. and M.M. Williams, II. 2018. Role of edamame (Glycine max) seed size in early season crop-weed interactions. Weed Sci. 66:746-751.

Dong, D., X. Fu, F. Yuan, P. Chen, S. Zhu, B. Li, Q. Yang, X. Yu, and D. Zhu. 2014. Genetic diversity and population structure of vegetable soybean (Glycine max (L.) Merr.) in China as revealed by SSR markers. Genet. Resources Crop Evol. 61:173-183.

Duppong, L.M. and H. Hatterman-Valenti. 2005. Yield and quality of vegetable soybean cultivars for production in North Dakota. HortTechnology 15:896-900.

Edwards, C.J. and E.E. Hartwig. 1971. Effect of seed size upon rate of germination in soybeans. Agron. J. 63:429-430.

Hamman, B., D.B. Egli, and G. Koning. 2002. Seed vigor, soilborne pathogens, preemergent growth, and soybean seedling emergence. Crop Sci. 42:451-457.

Hox, J.J. 2002. Multilevel analysis: Techniques and application. Lawrence Erlbaum, Mahwah, NJ.

Hoy, D.J. and E.E. Gamble. 1987. Field performance in soybean with seeds of differing size and density. Crop Sci. 27:121-126.

Hummel, J.W., L.E. Gray, and W.R. Nave. 1981. Soybean emergence from field seedbed environments. Trans. ASAE. 24:872-878.

Kering, M.K. and B. Zhang. 2015. Effect of priming and seed size on germination and emergence of six food-type soybean varieties. Inter. J. of Agron. Article 859212. doi:10.1155/ 2015/859212.

Longer, D.E., E.J. Lorenz, and J.T. Cothren. 1986. The influence of seed size on soybean (Glycine $\max ($ L.) Merrill) emergence under simulated soil crust conditions. Field Crops Res. 14:371375.

Madanzi, T., C. Chiduza, and S.J. RichardsonKageler. 2010. Effects of planting method and seed size on stand establishment of soybean [Glycine max (L.) Merrill cv. Solitaire]. Soil Tillage Res. 106:171-176.

Nafziger, E. 2009. Illinois Agronomy Handbook, 24th ed., p. 27-36. University of Illinois Extension, Champaign, IL.

Rao, M.S.S., A.S. Bhagsari, and A.I. Mohamed. 2002. Fresh green seed yield and seed nutritional traits of vegetable soybean genotypes. Crop Sci. 42:1950-1958.

Sanchez, E., K. Kelley, and L. Butler. 2005. Edamame production as influenced by seedling emergence and plant population. HortTechnology 15:672-676.

TeKrony, D.M., T. Bustamam, D.B. Egli, and T.W. Pfeiffer. 1987. Effects of soybean seed size, vigor, and maturity on crop performance in row and hill plots. Crop Sci. 27:1040-1045.

Williams, M.M.I.I. 2015. Phenomorphological characterization of vegetable soybean germplasm lines for commercial production. Crop Sci. 55:1274-1279.

Zhang, Q.Y., M. Hashemi, S.J. Hebert, and Y.S. Li. 2013. Different responses of preemergence and early seedling growth to planting depth between vegetable soybean and grain soybeans. Legume Res. 36:515-521. 